\title{
Generalized system of imposex and reproductive failure in female gastropods of coastal waters of mainland China
}

\author{
H. H. Shi ${ }^{1,2, *}$, C. J. Huang ${ }^{1}$, S. X. Zhu ${ }^{1}$, X. J. Yu ${ }^{1}$, W. Y. Xie ${ }^{1}$ \\ ${ }^{1}$ Institute of Marine Biology, Shantou University, Shantou 515063, PR China \\ ${ }^{2}$ Department of Environmental Sciences, East China Normal University, Shanghai 200062, PR China
}

\begin{abstract}
We investigated the occurrence of imposex in gastropods from the coastal waters of mainland China from November 1999 to July 2004. Imposex was found in 30 species from 8 families, and was recorded in 20 species for the first time. In addition to the already known phenotypes of imposex expression in Cantharus cecillei, we also found aborted egg capsules in specimens with a split ventral channel (stage and type classification: $\mathrm{S}_{6 c^{*}}$ ) and various extensions of the proximal vas deferens (PVD). The PVD went up to or passed by the vaginal opening, and then it stopped or continued along the capsule gland. In imposex females, the penis shape and the development of the vas deferens were similar to those of the male of the same species. The morphological expressions of imposex showed diverse stages and types. Reproductive failure of females occurred in 13 species. The results suggest that imposex is widespread and severe in the coastal waters of China. Based on our aims of ecological and morphological significance, a typical imposex classification could be further generalized for all 30 species by adding $S_{6 c}\left(^{*}\right)$ and 2 subdivisions of the PVD. The generalized scheme was also ascertained to be valid for several morphological variations of imposex in previous work. Sterility at $S_{6 c}\left(^{*}\right)$ was proven to be due to the infolding of the capsule gland wall. We thus summed up 4 mechanisms of sterility (a, b, c and ${ }^{*}$ ) in females. Furthermore, it was shown that the normal structure of the male genital system also affected the morphological expressions of imposex to some degree, which we referred to as 'effect of male structure'. Finally, we put forward a general classification scheme of imposex with an integrated system of aims, criteria, stages, types (subtypes), pathways and mechanisms of imposex.
\end{abstract}

KEY WORDS: Imposex $\cdot$ Gastropod $\cdot$ Sterility $\cdot$ Mainland China

Resale or republication not permitted without written consent of the publisher

\section{INTRODUCTION}

Imposex is the occurrence of male sex organs such as a penis and vas deferens in female gastropods (Smith 1971). This masculinization can lead to reproductive failure in females and even to the extinction of populations (Gibbs \& Bryan 1986). Imposex is mainly induced by organotin compounds used as biocides in antifouling paints (Smith 1981a,b,c, Bryan et al. 1987, 1988). To date, more than 170 species of gastropods, represented by 28 families, have been shown to be affected by imposex (Fioroni et al. 1991, deFur et al.
1999, Horiguchi et al. 2000; see Appendix 1, www.intres.com/articles/suppl/m304p179_app.pdf). However, on a worldwide scale, there is still a requirement to extend the scope of studies to include more tropical forms (Gibbs \& Bryan 1996).

A number of species show diverse morphological expressions of imposex. Fioroni et al. (1991) proposed an imposex classification scheme to outline these expressions based on the presence of a penis, the extension of the vas deferens and malformations of the pallial oviduct in 69 species. The scheme has been continuously modified (Oehlmann et al. 1991, 1992, 
1996, Stroben et al. 1992). In the typical scheme at present, imposex expressions are classified into 7 stages, with 3 types $(a, b, c)$ in the first 3 stages and Stage 5, and 2 types in Stages 4 and 6.

This scheme is generally valid for imposex descriptions in most prosobranch species and is widely used (Kohn \& Almasi 1993, Minchin et al. 1997, Bech 2002). However, since the characters of imposex show widely inter-specific, intra-specific and geographical differences (Fioroni et al. 1991), this typical imposex scheme will probably fail to cover all morphological variations. According to the references available, it is not appropriate for several of the main types of morphological expressions.

Firstly, aborted egg capsules may occur in Nassarius reticulatus (Buccinidae), even without any external signs of vulva blockage by vas deferens proliferation (Huet et al. 1995, Barreiro et al. 2001, Barroso et al. 2002). In Stage 4, the vas deferens develops from the base of the penis up to the vaginal opening $\left(\mathrm{S}_{4}\right)$, or passes by the vaginal opening and runs into the ventral channel of the capsule gland $\left(\mathrm{S}_{4^{*}}\right)$. Stroben et al. (1992) first distinguished $\mathrm{S}_{4}$. based on findings in $N$. reticulatus and regarded it as the end of imposex development in this species. However, later surveys suggested that sterility of $N$. reticulatus females appears to be a common phenomenon (Huet et al. 1995, Barreiro et al. 2001, Barroso et al. 2002).

Secondly, aborted egg capsules are often present in Hexaplex trunculus with a ventrally split pallial oviduct (Terlizzi et al. 2004). According to the typical scheme, a split pallial oviduct prevents copulation due to the open bursa copulatrix or egg capsule formation as a consequence of the open capsule gland. Therefore, it was argued that aborted egg capsules cannot be formed and consequently no $\mathrm{S}_{6 \mathrm{c}}$ stage should exist. However, the reports of aborted egg capsules in H. trunculus resemble Stage 6 in Nucella lapillus (Gibbs \& Bryan 1986, Terlizzi et al. 2004).

Thirdly, various extensions of the proximal vas deferens (PVD) occur in several species such as Lepsiella scobina, Nassarius reticulatus, Neptunea antiqua and Cantharus cecillei (Stewart et al. 1992, Power \& Keegan 2001, Barroso et al. 2002, Shi et al. 2005). In the typical scheme, the PVD either joins the vaginal opening or passes by it and enters the capsule gland. In some species, however, the PVD also extends laterally after joining the vaginal opening, or passes by the vaginal opening and just ends in the posterior section of the pallial cavity (Fioroni et al. 1991).

Finally, a penis may be lacking and yet, vas deferens formation may be weak in imposex-affected females of Nucella lapillus. This phenomenon was first reported in a restricted area in Southeast England by Gibbs (1993) who called it the Dumpton Syndrome (DS). In the typical scheme, a penis is regarded as a conspicuous masculine character and the complete penis will be formed at least in Stage 4. However, sterility may occur in females of $N$. lapillus without formation of a penis (Huet et al. 1996, Barreiro et al. 1999).

Such conspicuous variations usually cause confusion when classifying the morphological expressions of imposex. It is sometimes difficult to distinguish the stages in some species (Power \& Keegan 2001). For example, Hexaplex trunculus with aborted egg capsules is still classified as Stage 5 (Axiak et al. 1995). To make the identification easy, several schemes are proposed for specific species, based on different criteria (Axiak et al. 1995, Barreiro et al. 1999, Mensink et al. 2002). For example, Barreiro et al. (1999) proposed a specific scheme for DS in Nucella lapillus solely based on vas deferens development instead of vas deferens and penis development in the typical scheme.

Subsequently, the variability in the classification makes the assessment of imposex problematic when comparing different investigations if different values of the vas deferens sequence index (VDSI) are used for the same expression (Ruiz et al. 2005). For example, the VDSI of Nassarius reticulatus at $\mathrm{S}_{4}$ * has been computed as 4.0, 4.5 and 5.0 by different researchers (Stroben et al. 1992, Barreiro et al. 2001, Barroso et al. 2002).

In addition, the mechanisms of sterility are still ambiguous in Nassarius reticulatus and Hexaplex trunculus. The classification is just based on the hypothesis that the degree of imposex will be upgraded along the scheme. Therefore, if the mechanisms are not clearly revealed, it is hard to classify the expression of imposex reasonably. To date, 2 mechanisms have been described (Gibbs \& Bryan 1996, Oehlmann et al. 1998). One mechanism is the blockage of the vulva by vas deferens tissue or the replacement of the vulva by the prostate, the other is the presence of a longitudinal split in the capsule gland of the adult. It is assumed that aborted egg capsules can only be formed in the first case. However, neither mechanism above completely fits the formation of aborted egg capsules in $N$. reticulatus or $H$. trunculus, and new mechanisms have not yet been revealed.

Gibbs \& Bryan (1996) supposed that the male structure provides important clues as to the net effect of imposex when the female individual is promoted to an advanced stage. Muricidae are prone to sterility because the male tract follows the same path within the mantle cavity as that of the female tract. The pallial vas deferens of males in other groups is parallel to the extension of the oviduct in females. In these cases, the vas deferens of imposex individuals contacts the oviduct some distance behind the genital papilla and 
does not interfere with copulation or capsule release. However, sterility still occurs in families other than Muricidae such as Buccinidae (Barreiro et al. 2001, Shi et al. 2005). Therefore, it is not clear whether sterility can be predicted from the male structure.

Currently, these variations give rise to some confusion about the classification of imposex, the assessment of the VDSI and the mechanisms of sterility. Therefore, the typical scheme needs suitable modification and other mechanisms remain to be discovered.

China has a $3200 \mathrm{~km}$ long coastline, a rich gastropod fauna and severe organotin compound contamination (Jiang et al. 2001), but surveys of imposex are rarely conducted. For the first time, we investigated imposex on a large scale along the coastal waters of mainland China from November 1999 to July 2004. In our previous study, we modified the typical imposex scheme to suit Cantharus cecillei by adding Types a*, $\mathrm{b}^{*}$ and $\mathrm{c}^{*}$ as new types, and rearranging Type $4^{*}$ to be parallel to Type 4 (Shi et al. 2005). To generalize the updated scheme for C. cecillei, we needed to investigate more species and to ascertain the full range of their imposex expressions.

In the present study, we collected and examined more than 12000 specimens of gastropods along the coastal waters of mainland China. Morphological parameters and imposex expression were determined, and the mechanisms of reproductive failure in females were also revealed based on anatomical and histological observations. Our objectives were to (1) determine imposex-affected species and their morphological expressions along the coastal waters of mainland China, (2) ascertain whether the modified classification scheme would be valid for these species, and (3) reveal the mechanisms of sterilization in females.

\section{MATERIALS AND METHODS}

Gastropods were collected during low tide or bought from the fishermen along the coastal waters of mainland China (Fig. 1). From November 1999 to July 2004, the external topography of 12000 specimens in 54 species was analyzed. The animals were narcotized using $7 \% \mathrm{MgCl}_{2}$ in distilled water and the shells were cracked with a vice. The fresh soft bodies were first observed and measured quickly using a magnifier. They were then fixed and preserved in $4 \%$ formaldehyde, and observed under a Carl Zeiss Stemi SV11 dissecting microscope. Two hundred and forty specimens preserved in formaldehyde were embedded in paraffin and thinly-sectioned $(5 \mu \mathrm{m})$. After being stained with hematoxylin-eosin, the sections were analyzed under a Carl Zeiss Axioplan 2 microscope. Micrographs were taken with a Carl Zeiss Axiocam and analyzed using Axio Vision 3.0. One hundred and sixty specimens for scanning electron micrographs were fixed in glutaraldehyde directly after narcotization in $\mathrm{MgCl}_{2}$. Samples were dehydrated via a graded ethanol series, critical point dried and coated with gold. Lastly, they were examined with a Philip scanning electron microscope XL-30.

Individuals with testes, a penis, vas deferens and a prostrate were regarded as male; individuals with ovaries, a capsule gland, an albumen gland and a sperm-ingesting gland were regarded as female; females having male sex organs such as a penis or vas deferens were considered to be imposex individuals. Species with imposex individuals were considered as imposex species. The morphological expressions of male, female and imposex individuals were recorded in detail.

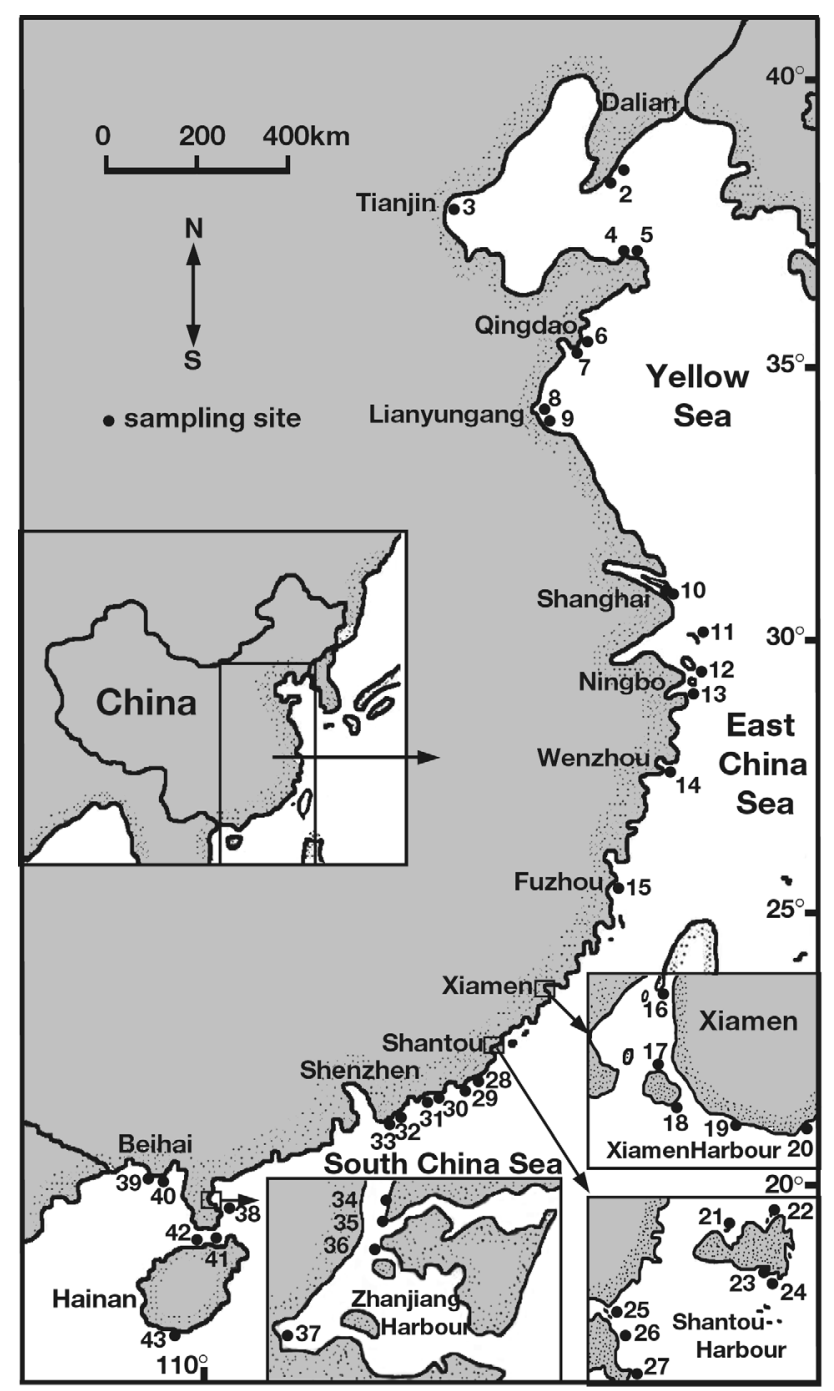

Fig. 1. Collection areas for gastropods in the coastal waters of mainland China 


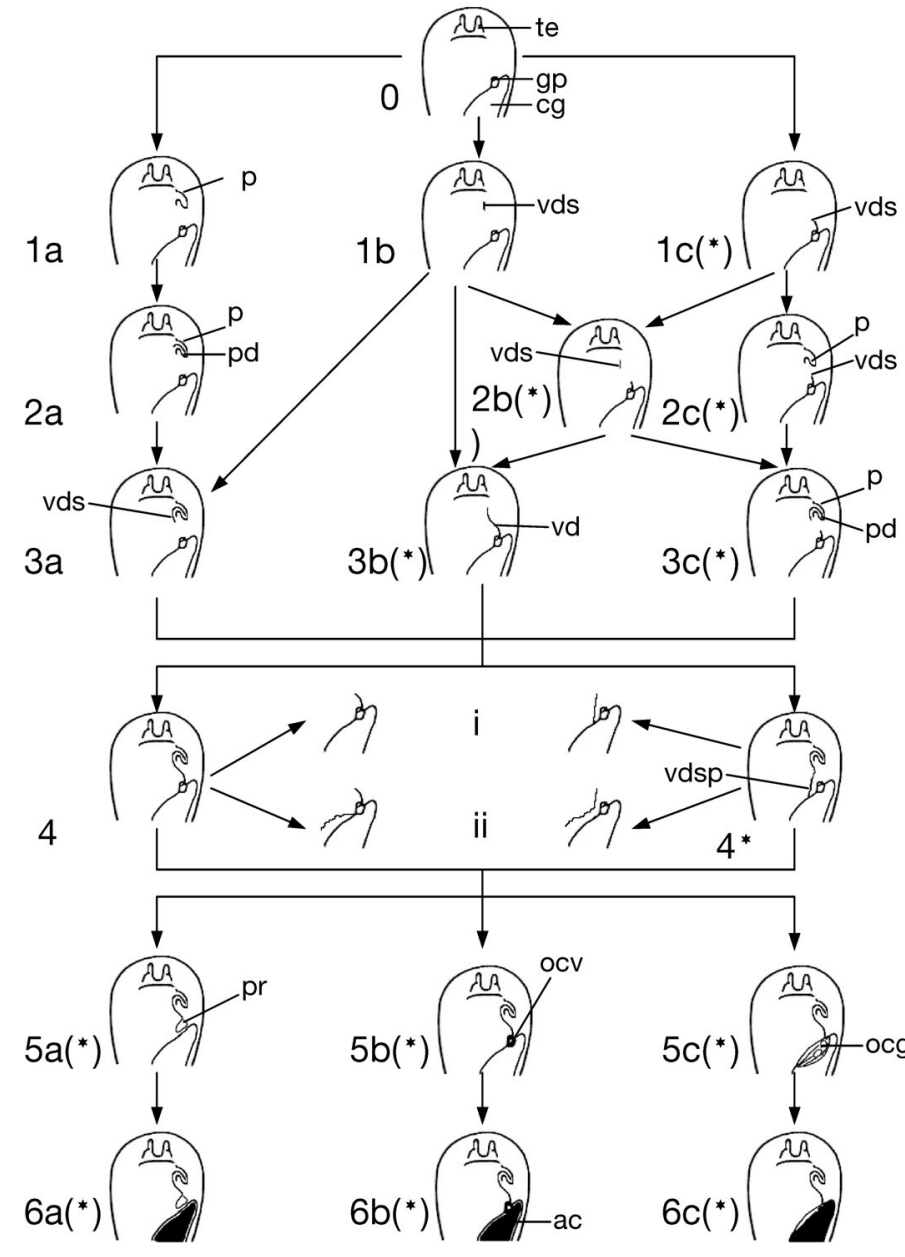

Fig. 2. Generalized scheme of imposex in prosobranchs (modified from Shi et al. 2005). The development of imposex was classified into 7 stages $(0-6)$ with 6 types $\left(a, b, c, a^{*}, b^{*}\right.$ and $\mathrm{c}^{*}$ ). The types and stages are described in 'Materials and methods'. Due to limited space in the scheme, only the models of Types $\mathrm{a}, \mathrm{b}$ and $\mathrm{c}$ are described and Types $\mathrm{a}\left({ }^{*}\right), \mathrm{b}\left({ }^{*}\right)$ and $\mathrm{C}\left({ }^{*}\right)$ mentioned beside them. Type 4 and Type $4^{*}$ are still separated, and Type $\left({ }^{*}\right)$ in any other stage actually includes 2 types and subtypes (i and ii) like the layout in Stage 4 . Two subtypes means that the vas deferens either enter the capsule gland (i) or run along it (ii). Types $\mathrm{a}\left({ }^{*}\right)$ stand for Type a and Type $\mathrm{a}^{*}$, so too do Types $\mathrm{b}\left({ }^{*}\right)$ and $\mathrm{c}\left({ }^{*}\right)$. ac: aborted capsules; cg: capsule gland; gp: genital papilla; ocg: open capsule gland; ocv: occlusion of the vulva; $\mathrm{p}$ : penis; pd: penis duct; pr: prostate; te: tentacle; vd: vas deferens; vds: vas deferens section; vdsp: vas deferens section passage by the vaginal opening

The stages and types of imposex development were defined according to the updated scheme of imposx by Shi et al. (2005) with further modification (Fig. 2). The detailed definition is as follows:

Stage 0. Normal female without any male characteristics.

Stage 1. Type a: Tiny penis, without a penis duct, behind the right ocular tentacle. Type b: Short, distal vas deferens tract behind the right ocular tentacle. Type c, C* : Short, proximal vas deferens tract beginning at (Type c) or passing by (Type $\mathrm{C}^{*}$ ) the vaginal opening.

Stage 2. Type a: Penis with a penis duct behind the right ocular tentacle. Type $b, b^{*}$ : A short, distal vas deferens tract behind the right ocular tentacle and a PVD beginning at (Type b) or passing by (Type $b^{*}$ ) the vaginal opening. Type $\mathrm{c}_{1} \mathrm{C}^{*}$ : Small penis and a short PVD beginning at (Type c) or passing by $\left(\right.$ Type $\mathrm{c}^{*}$ ) the vaginal opening.

Stage 3. Type a: Penis with a penis duct continuing in a short distal tract of the vas deferens. Type $b, b^{*}$ : Vas deferens running continuously from the right ocular tentacle over the bottom of the mantle cavity up to (Type b) or passing by (Type $b^{*}$ ) the vaginal opening. Type $\mathrm{c}_{1} \mathrm{C}^{*}$ : Penis with a penis duct continuing in a distal portion of the vas deferens; additionally, a short PVD portion beginning from (Type c) or near (Type $\mathrm{C}^{*}$ ) the vaginal opening.

Stage 4. Type 4: Penis with a penis duct and a continuous vas deferens from the penis up to the vaginal opening. Type $4^{*}$ : Penis with a penis duct and a continuous vas deferens running from the penis and passing by the vaginal opening.

Stage 5. Type a: A reduced vagina and an absent vulva. A more or less extended prostate gland at the vaginal opening. Type $\mathrm{a}^{*}$ : A complete vagina and an open vulva with a more or less extended prostate gland near the vaginal opening. Type b: Vaginal opening occluded by proliferating vas deferens tissue, often forming 'nodules'. Type $\mathrm{b}^{*}$ : An open vulva with a reduced, blocked or contorted pallial oviduct. Type $\mathrm{C}_{\text {, }}$ $\mathrm{C}^{*}$ : Incomplete ontogentic closure of the pallial oviduct and a continuous vas deferens up to (Type c) or passing by (Type $\mathrm{c}^{*}$ ) the vaginal opening.

Stage 6. Type $a, a^{*}, b, b^{*}, c$ and $c^{*}$ differed from the corresponding type of Stage 5 by the presence of aborted egg capsules in their oviduct.

\section{RESULTS}

A total of 54 species from 12 families were collected and 30 species in 8 families showed imposex (Appendix 2, see www.int-res.com/articles/suppl/ m304p179_app.pdf). Most of the species that exhibited imposex belonged to 3 families: Muricidae (14), Buccinidae (6) and Nassidae (3). Imposex-affected species included inter- and subtidal ones. Thais clavigera was the most encountered species, followed by T. gradata and T. luteostoma. The incidence of imposex in $T$. clavigiera was more than $90 \%$ at most collection sites.

All the expressions in the scheme and various extensions of the vas deferens were found (Fig. 2). In $\mathrm{S}_{6 \mathrm{c}^{*}}$, 
the capsule gland wall infolded internally while the ventral channel was split open to the cavity (Fig. 3a,b). The bursa copulatrix was unaffected and the internal wall of the capsule gland remained closed. The PVD showed diverse variations. It often joined and ended in the vaginal opening (Fig. 3c), or passed by the vaginal opening and entered the capsule gland (Fig. 3d). In addition, it joined the vaginal opening and extended rearward (Fig. 3e), or passed by the vaginal opening and ran parallel to the capsule gland (Fig. 3f).

Some additional expressions were also found. Bi- or multi-furcate penes were found in males and females. The vas deferens could be branched. Excrescences consisting of hyperplasic tissues arose on the bottom of the mantle cavity or on the penis and the vas deferens.

The morphological expressions of imposex were similar to those of males in the same species. The penis of male Thais clavigera had a thick cylindrical base and a slim cylindrical end, as did that of imposex individuals (Fig. 4a,b). Penes in male and imposex females of Cantharus cecillei had a penis sheath (Fig. 4c,d). Male Babylonia areolata was characterized by a closed vas deferens, and imposex individuals first showed an open vas deferens which then developed into a closed one (Fig. 4e-g). Male C. cecillei had a special prostrate with a twisting vas deferens, and a similar structure was also found in imposex females (Fig. $4 \mathrm{~h}-\mathrm{j}$ ).

The stages and types of imposex in all species were defined according to the descriptions above. The severity of imposex showed great intra-specific variability (Appendix 2). Cantharus cecillei had the highest diversity in stages and types, followed by Babylonia formosae habei, Thais clavigera and T. luteostoma. Some species, such as Cymbium melo and Tonna sulcosa, exhibited only 1 or 2 stages. The highest imposex levels showed greater inter-specific difference (Appendix 2). The final stage of imposex in 17 species was no less than Stage 4, while in the remaining 13 species sterile females occurred, reaching Stage 5 or 6 . The types also differed in the frequency of occurrence. Type a was the most prevalent in $\mathrm{S}_{1}$ to $\mathrm{S}_{3}, \mathrm{~S}_{4}$ was more abundant than $\mathrm{S}_{4}{ }^{*}$, and Type $\mathrm{b}$ dominated at Stages 5 and 6 . Type* was widespread in C. cecillei and also encountered in other species such as Chicoreus asianus, C. brunneus and B. areolata.

\section{DISCUSSION}

\section{Imposex-affected species}

Except for Neverita didyam, Ergalatax contractus, Thais clavigera, T. distinguenda, T. gradata, T. luteostoma, Rapana venosa, Babylonia areolata, Cantharus cecillei and Nassarius siquijorensis (Liu \& Suen
1996, Tan 1999, Horiguchi et al. 2000, Li 2000, Bech 2002, Shi et al. 2005), imposex of the other 20 species was reported for the first time. The number of known imposex-affected species therefore increased to 195 in total (Fioroni et al. 1991, deFur et al. 1999; Appendix 1). This suggests that the list of imposex species would certainly become longer with further investigation, and the deleterious effects of organotin contamination on gastropods would probably be far greater. Of all affected species, more than half came from the families Muricidae (76), Buccinidae (26) and Conidae (17). This indicated that imposex was more family-specific while species-universal.

Species showing sterile females (13) accounted for nearly half of all imposex species (30). It was the first time that sterility was found in Cypreaidae and Conidae. Though imposex has been reported in Chioreus spp. and Babylonia spp. (Liu \& Suen 1996, Tan 1999), no sterility has been found in these species in previous studies. In addition, our collection areas covered all the main ports in mainland China. Thais clavigera, one of the most encountered species in tropical coast, showed an imposex incidence of more than $90 \%$ at most collection sites. Therefore, the present results clearly indicate that imposex is not only widespread but also severe in the coastal waters of mainland China. Imposex can be induced by tributyltin (TBT) at concentrations as low as the ng Sn $\mathrm{l}^{-1}$ level (Bryan et al. 1987, 1988). TBT has been detected $\left(>0.5 \mathrm{ng} \mathrm{Sn}^{-1}\right)$ at 21 of 32 sampling sites in the selected lakes, rivers and coastal environments of China (Jiang et al. 2001). The highest levels of TBT are observed in several main ports such as Dalian (203.7 ng Sn $\mathrm{l}^{-1}$ ), Tianjing (322.4 ng Sn $^{-1}$ ), Qingdao

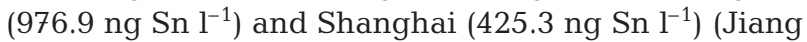
et al. 2001). These facts indicate that organotin pollution is also widespread and severe in China, which might be the main reason for the induction of imposex in gastropods along the coastal waters of China.

\section{Aims and criteria of a classification scheme}

Up to date, different criteria-dependent schemes have been proposed for the description of imposex (Axiak et al. 1995, Barreiro et al. 1999, Mensink et al. 2002). To make a scheme more applicable for general use, 2 questions should first be clarified: (1) What is the purpose of scheme? We think a scheme should possess ecological and morphological significance (Fig. 5). On the one hand, it should be used for gauging the intensity of imposex. On the other hand, it should reflect the mechanisms of imposex development and sterility in females. Both aspects are closely related. For example, changes in population dynamics can be 

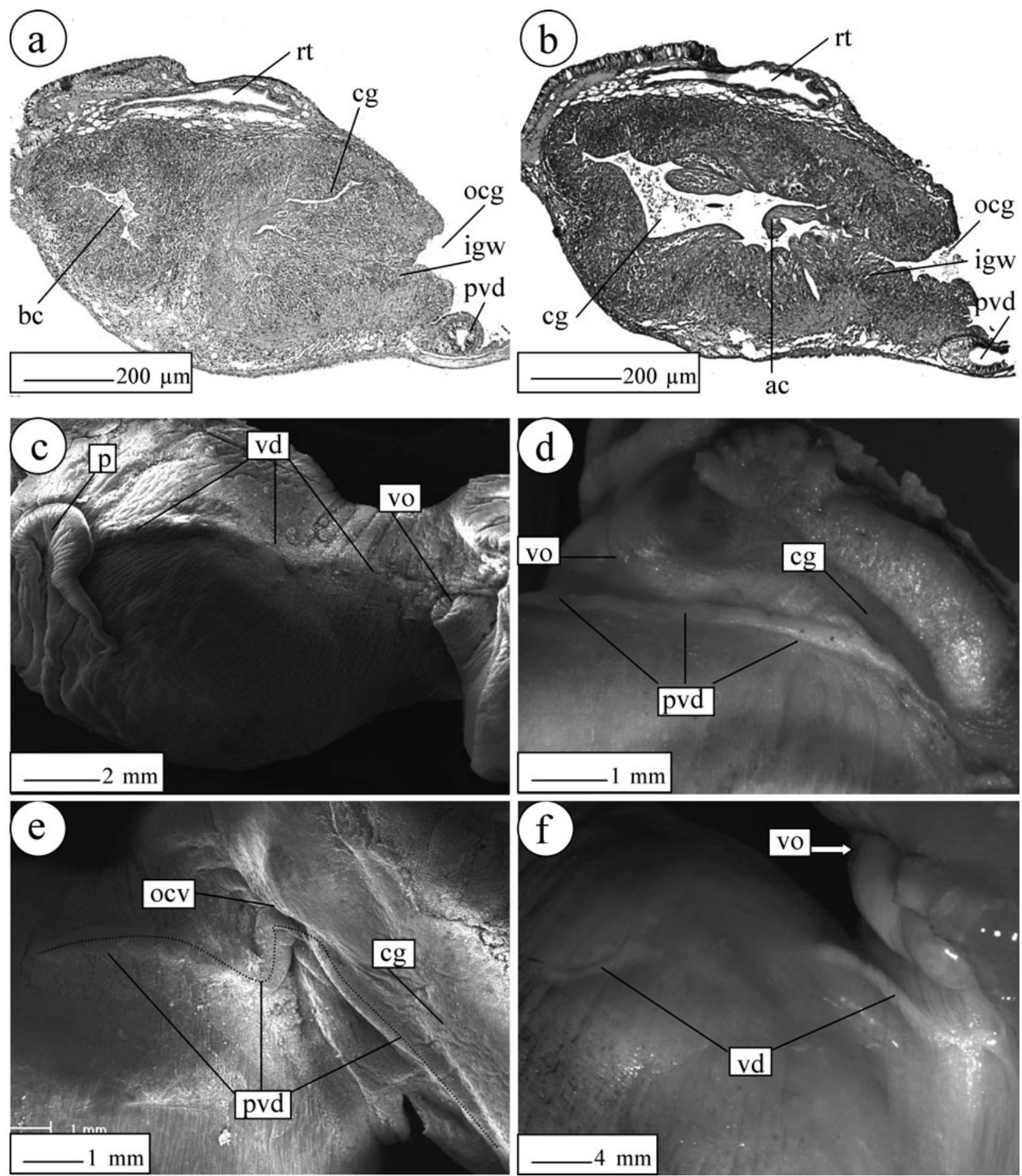

Fig. 3. Cantharus cecillei, Thais clavigera and Babylonia areolata. Morphological expressions of imposex in gastropods from the coastal waters of mainland China. $(\mathrm{a}, \mathrm{b})$ Histological photographs of $C$. cecillei at $\mathrm{S}_{6 \mathrm{c}}{ }^{*}$, ventrally split ventral channel and infolding gland wall with aborted egg capsules. Sections of (a) anterior and (b) posterior parts of the capsule gland. (c) SEM photograph of T. clavigera at $\mathrm{S}_{4}$. The PVD joined and ended in the vaginal opening. (d,e) SEM photographs of C. cecillei at (d) $\mathrm{S}_{6 \mathrm{~b}}$. and (e) $S_{6 b}$. The PVD passed by the vaginal opening and entered the capsule gland (d), or joined the vaginal opening and extended forward (e). (f) Anatomical photograph of $B$. areolata at $\mathrm{S}_{2 \mathrm{~b}}$, a short distal vas deferens and a proximal vas deferens passing by the vaginal opening and running parallel to the capsule gland. bc: bursa copulatrix; igw: infolding gland wall; pvd: proximal vas deferens; rt: rectum; vo: vaginal opening 

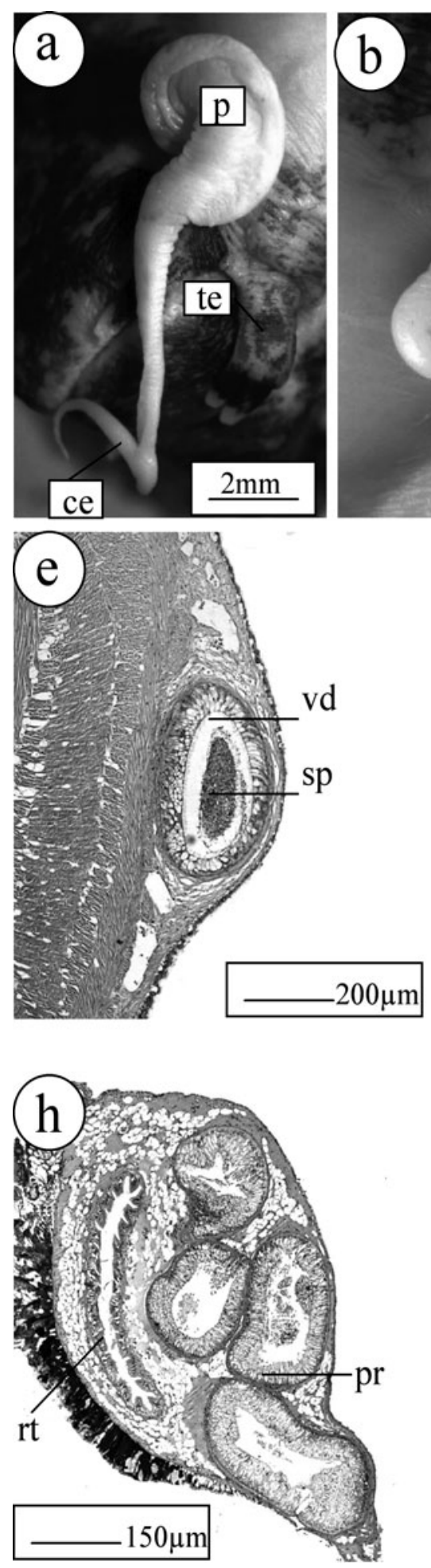
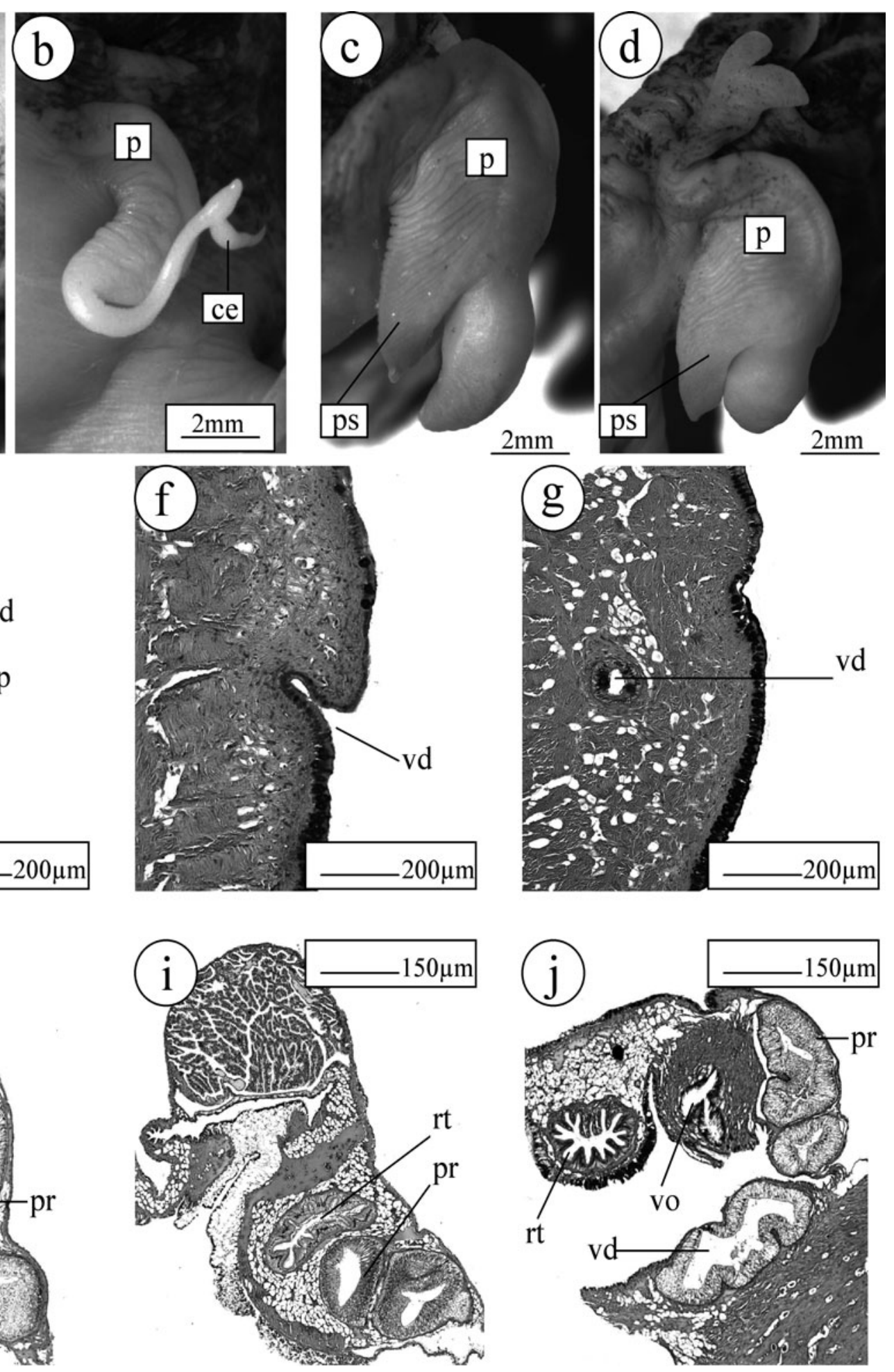

Fig. 4. Thais clavigera, Babylonia areolata and Cantharus cecillei. Characters of penes, vas deferens and prostrates in male and imposex individuals of gastropods from the coastal waters of mainland China. (a-d) Anatomical photographs of penes. (a) Male individual and (b) imposex individual at $\mathrm{S}_{4}$ of $T$. clavigera, and (c) male individual and (d) imposex individual at $\mathrm{S}_{4}$. of $B$. areolata; $(\mathrm{e}-\mathrm{g})$ Sections of vas deferens in B. areolata. (e) Male individual and (f) imposex individual at $\mathrm{S}_{1 \mathrm{~b}}$ and $(\mathrm{g})$ at $\mathrm{S}_{4}{ }^{*}$ ( $(\mathrm{h}-\mathrm{j}) \mathrm{Sections}$ of prostrate of C. cecillei. (h) Male individual and (i) imposex individual at $\mathrm{S}_{5 \mathrm{a}}$ and (j) at $\mathrm{S}_{6 \mathrm{a}}$. ce: cylindrical end; sp: sperm; ps: penis sheath 
predicated based on the mechanisms of sterility in females. In addition, the mechanisms of morphological expressions might further provide important clues for revealing the biochemical mechanisms of imposex induced by pollutants. (2) What are the criteria for proposing a scheme? Barreiro et al. (1999) thought the adoption of only 1 criterion to be most reasonable. One criterion based upon vas deferens development might be valid for DS in Nucella lapillus, but not for general use even in this species. Other schemes for specific species are faced with similar difficulties. Actually, the typical scheme is based on 3 criteria: (1) occurrence of a penis, (2) extension of the vas deferens and (3) oviduct malformation. Penis expression is particularly useful in areas of trace contamination, and information on vas deferens formation and oviduct malformation becomes more relevant at higher contamination levels (Gibbs \& Bryan 1996). The typical scheme reflects the complicated process of imposex development with diverse masculine characteristics. In the present paper, a general scheme was required to detect 30 imposex species. Therefore, we would still follow the typical one.

\section{A generalized scheme}

In this study, we found diverse morphological expressions, some of which were not covered by the typical scheme but by the updated one for Cantharus cecillei (Shi et al. 2005). For example, Type * also occurred in several species in addition to C. cecillei
(Appendix 2), including specimens with an open vulva or aborted egg capsules. Therefore, the updated scheme for $C$. cecillei could be generalized in the present study. Nevertheless, further modification was required to satisfy several variations. Aborted egg capsules in $C$. cecillei with a split ventral channel suggested that $S_{\left.5 c^{*}\right)}$ could develop to $S_{\left.6 c c^{*}\right)}$ (Fig. 3a,b). This hypothesis was also supported by the proposal of Stage 6 in Hexaplex trunculus (Terlizi et al. 1999, Pellizzato et al. 2004). Therefore, $\mathrm{S}_{6 \mathrm{c}(*)}$ should be added to the generalized scheme.

In each $\mathrm{S}_{\mathrm{nm}(*)}$ (where $\mathrm{n}$ represents 1 stage and $\mathrm{m}$ represents 1 type), we subdivided the PVD into 2 subtypes ( $i$ and ii) according to its external sign of extension. Subtypes in $\mathrm{S}_{\mathrm{nm}}$ were defined as the PVD joining and ending in the vulva (i), or passing by the vulva and entering the capsule gland (ii). Correspondingly, subtypes in $\mathrm{S}_{\mathrm{nm}}$. were defined as the PVD joining the vaginal opening and being separated from the capsule gland (i), or passing by the vulva and extending parallel to the capsule gland (ii). Due to limited space, we have only listed the model of 2 subtypes in Stage 4 ,

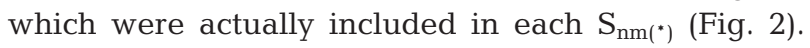
The subdivision did not only cover all main variations of the PVD but was also useful for the determination of mechanisms of sterility in females.

The generalized scheme also made the classification of imposex and assessment of the VDSI for several main variations clear in previous attempts (Ruiz et al. 2005). For example, the sterile female in Nassarius reticulatus could be classified as Stage 5 or 6, and the score would be correspondingly calculated as 5 or 6 .

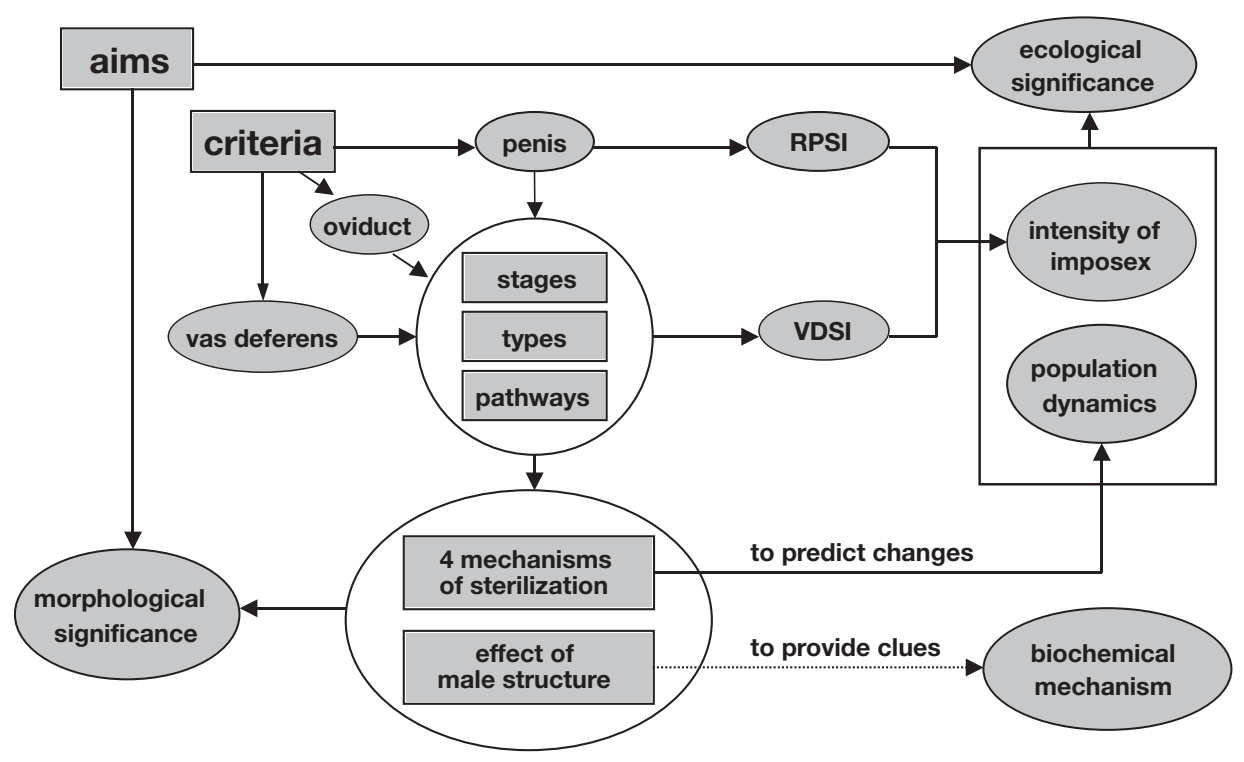

Fig. 5. Integrated classification scheme of imposex in gastropods. RPSI: relative penis size index; VDSI: vas deferens sequence index 
Then the correlation between the VDSI and the relative penis size index (RPSI) across samples would be improved, resulting in an increased power of discrimination (Barreiro et al. 2001, Barroso et al. 2002).

The generalized scheme might not cover all the small variations. However, it would still be valid for specific species after a little modification. For example, it seemed invalid for the DS in Nucella lapillus. Actually, DS is a very special and rather localized phenomenon, mainly controlled by genetic factors (Gibbs 1993, 2005, Huet et al. 1996). Nevertheless, Path $\mathrm{b}$ in the generalized scheme could still be modified to suit DS in $N$. lapillus without regard to a penis in Stages 5 and 6 temporarily. On the contrary, it is biased to negate the typical scheme only because it cannot fit a specific species (Barreiro et al. 1999). In all, the generalized scheme was valid for all the main morphological expressions of imposex found at present (Fig. 2).

\section{Mechanisms of sterility in females}

The mechanisms of sterilization in females with Types a and b have been described. As for Type*, the mechanisms could be distinguished in terms of 2 subtypes of the PVD. For Subtype ii, we could deduce that it was the inner change of the pallial oviduct that led to the sterility in females because the PVD did not disturb the vaginal opening or the pallial oviduct. For Subtype $i$, the inner change was still the reason for sterility in Cantharus cecillei because the PVD was proven not to extend or block the pallial oviduct directly (Shi et al. 2005). In Nassarius reticulatus though, the vas deferens enters the capsule gland, and external inspection has failed to reveal what happens to the vas deferens once it stops outside the gland or keeps growing within the ventral channel (Barreiro et al. 2001). Therefore, the PVD was only a possible reason for sterility in Subtype i $N$. reticulatus.

The histological sections suggested that the formation of aborted egg capsules in Cantharus cecillei of Type* was due to the folding of the capsule gland wall (Fig. 3a,b). On one hand, copulation could be achieved because the bursa copulatrix was still complete. On the other hand, the egg capsules could not be released because the internal wall of the capsule gland was still closed. Therefore, the egg capsules would be aborted once the pallial oviduct was blocked. No detailed information was available for Hexaplex trunculus with exteriorly aborted egg capsules, but we could suppose that the inner change might have led to the formation of aborted egg capsules.

According to the types and paths of imposex, we classified the mechanisms of sterility in females into (a) replacement of the vulva by the prostate gland, (b) blockage of the vaginal opening by the vas deferens, (c) a split capsule gland and ( ${ }^{*}$ ) blockage of the pallial oviduct duct by inner change or the PVD. One species might have several mechanisms of sterility. For example, in Nassarius reticulatus, it has been reported that the vulva can be externally obstructed or covered with tissue excrescence (b) (Barroso et al. 2002). In addition, aborted egg capsules are also found in female $N$. reticulatus with an open vulva $\left({ }^{*}\right)$ (Huet et al. 1995, Barreiro et al. 2001, Barroso et al. 2002). The mechanisms were accordant with the types and stages of imposex (Fig. 2; Appendix 2). Cantharus cecillei showed the most diverse mechanisms of sterility in females.

\section{Effect of male structure}

Our results did not fully support the prediction of net effect of imposex based on male structure by Gibbs \& Bryan (1996) because sterility also occurred in other families such as Buccinidae and Conidae. On one hand, male structure actually affected the morphological and histological characteristics of imposex in at least 3 aspects (Fig. 4). Firstly, the shape of masculine organs in the female followed that in the male. For example, the special male structure of Cantharus cecillei could be copied in imposex individuals, resulting in diverse PVDs and mechanisms of sterility (Shi et al. 2005; Fig. $4 \mathrm{~h}-\mathrm{i}$ ). Secondly, the development of masculine organs in the female was similar to that in the male. For example, the closed vas deferens is supposed to arise by fusion of the edges of an open groove, which can be transferred to the oviduct as part of the masculinizing process during the development of the female tract (Gibbs \& Bryan 1996). It is the underlying reason for the split capsule gland in females which could be further proven by results in Babylonia areolata (Fig. 4e-g). Finally, the paths of imposex development also followed the course of males (Fig. 3). For example, Path $1 \mathrm{a} \rightarrow 2 \mathrm{a} \rightarrow 3 \mathrm{a} \rightarrow 4 \rightarrow 5 \mathrm{~b} \rightarrow 6 \mathrm{~b}$ was the most popular in Muriciade, while Path* was more often encountered in Buccinidae. This was due to the different development of the vas deferens in males of 2 families. On the other hand, the paths of imposex did not fully follow the tract of male structure. Sterile females were still found in Buccinidae and Conidae. This finding disproved the predication that sterility would not occur in groups other than Muricidae (Gibbs \& Bryan 1996).

Therefore, to include these new findings, we modified this hypothesis to 'male structure would not determine but affect imposex expressions to some degree during the development of imposex in gastropods'. We call this phenomenon 'effect of male structure'. 
It is accepted that imposex is associated with elevated testosterone levels (Spooner et al. 1991), which might be induced by 2 mechanisms. One is the inhibition of the aromatase enzyme which converts testosterone to estradiol (Spooner et al. 1991). The other is the interference with the metabolic elimination of testosterone (Ronis \& Mason 1996). TBT has been proved to interfere with the esterification of testosterone, resulting in elevated free testosterone levels (Gooding et al. 2003). In a recent study, Nishikawa et al. (2004) suggested that retinoid $\mathrm{X}$ receptors play an important role in inducing the development of imposex. To date, although several hypotheses have been proposed, the exact biochemical mechanisms of imposex have not yet been fully revealed (Matthiessen \& Gibbs 1998).

The principle of morphological changes might provide useful clues for revealing the mechanism or evidence for confirming the putative mechanism of imposex (Gibbs 2005). Any morphological expressions of imposex must start with changes of biochemical levels in organisms. Biochemical changes determine morphological expressions. Morphological expressions, in contrast, can reflect biochemical changes. Especially the 'effect of male structure' should be an important principle in imposex development, and is closely related to the intrinsic characters of species and even ecospecies. For example, DS is clearly controlled by genetic factors (Gibbs 1993, 2005, Huet et al. 1996). However, no reports of biochemical mechanisms have been linked to the principle of morphological development in previous studies. Therefore, further efforts should be made to find clues for revealing the biochemical mechanisms involved in the morphological expressions of imposex.

\section{CONCLUSIONS}

To date, the imposex classification scheme has been modified many times from simplicity and faultiness to complexity and relative perfection. We modified a few aspects of the typical scheme. In our opinion, the classification scheme should be an integrated system consisting of aims, criteria, stages, types (subtypes), pathways and mechanisms of imposex (Fig. 5), and all aspects should be internally relative. The generalized system was valid for all the main morphological expressions of imposex species in gastropods at present. It not only could be used for the classification and evaluation of the intensity of imposex but also reflected the mechanisms of imposex development and sterility in females. The principle of 'effect of male structure' in imposex development might provide clues for further revealing biochemical mechanisms of imposex induced by pollutants.
Acknowledgements. We thank J. Oehlmann for his comments on the manuscript. This study was supported by a Grant-in-Aid from the National Natural Sciences Foundation of China (40176029).

\section{LITERATURE CITED}

Axiak V, Vella AJ, Micallef D, Chircop P, Mintoff B (1995) Imposex in Hexaplex trunculus (Gastropoda: Muricidae): first results from biomonitoring of tributyltin contamination in the Mediterranean. Mar Biol 121:685-691

Barreiro R, Quintela M, Ruiz JM (1999) Aphally and imposex in Nucella lapillus from Galicia (NW Spain): incidence, geographical distribution and consequences for the biomonitoring of TBT contamination. Mar Ecol Prog Ser 185:229-238

Barreiro R, González R, Quintela M, Ruiz JM (2001) Imposex, organotin bioaccumulation and sterility of female Nassarius reticulatus in polluted areas of NW Spain. Mar Ecol Prog Ser 218:203-212

Barroso CM, Moreira MH, Bebianno MJ (2002) Imposex, female sterility and organotin contamination of the prosobranch Nassarius reticulatus from the Portuguese coast. Mar Ecol Prog Ser 230:127-135

Bech M (2002) A survey of imposex in muricids from 1996 to 2000 and identification of optimal indicators of tributyltin contamination along the east coast of Phuket Island, Thailand. Mar Pollut Bull 44:887-896

Bryan GW, Gibbs PE, Burt GR, Hummerstone LG (1987) The effects of tributyltin accumulation on adult dog-whelks. Nucella lapillus: long-term field and laboratory experiments. J Mar Biol Assoc UK 67:524-544

Bryan GW, Gibbs PE, Burt GR (1988) A comparison of the effectiveness of tri-n-butyltin chloride and five other organotin compounds in promoting the development of imposex in the dog-whelk, Nucella lapillus. J Mar Biol Assoc UK 68:733-744

deFur PL, Crane M, Ingersoll CG, Tattersfield LJ (1999) Endocrine disruption in invertebrates: endocrinology, testing and assesment. Society of Environmental Toxicology and Chemistry (SETAC), Pensacola, FL

Fioroni P, Oehlmann J, Stroben E (1991) The pseudohermaphroditism of prosobranchs, morphological aspects. Zool Anz 226:1-26

Gibbs PE (1993) A male genital defect in the dog-whelk, Nucella lapillus (Neogastropoda), favoring survival in a TBT-polluted area. J Mar Biol Assoc UK 73:667-678

Gibbs PE (2005) Male genital defect (Dumpton Syndrome) in the dog-whelk Nucella lapillus (Neogastropoda): Mendelian inheritance inferred, based on laboratory breeding experiments. J Mar Biol Assoc UK 85:143-150

Gibbs PE, Bryan GW (1986) Reproductive failure in populations of the dog-whelk, Nucella lapillus, caused by imposex induced by tributyltin from antifouling paints. J Mar Biol Assoc UK 66:767-777

Gibbs PE, Bryan GW (1996) TBT-induced imposex in neogastropod snails: masculinization to mass extinction. In: de Mora SJ (ed) Tributyltin: case study of an environmental contaminant. Cambridge University Press, Cambridge

Gooding MP, Wilson VS, Folmar LC, Marcovich DT, LeBlanc GA (2003) The biocide tributyltin reduces the accumulation of testosterone as fatty acid esters in the mud snail (Ilyanassa obsoletea). Environ Health Persp 111:426-430

Horiguchi $T$, Cho $H$, Shiraishi $H$, Shibata $Y$, Morita $M$, Shimizu M (2000) Temporal trends and present status on imposex and organotin contamination in gastropods. Bull 
Coast Oceanogr 37:89-95 (in Japanese)

Huet M, Fioroni P, Oehlmann J, Stroben E (1995) Comparison of imposex response in three Prosobranch species. Hydrobiologia 309:29-35

Huet M, Paulet YM, Pennec M (1996) Survival of Nucella lapillus in a tributyltin-polluted area in West Brittany: a further example of a male genital defect (Dumpton syndrome) favouring survival. Mar Biol 125:543-549

Jiang GB, Zhou QF, Liu JY, Wu DJ (2001) Occurrence of butyltin compounds in waters of selected lakes, rivers and coastal environments from China. Environ Pollut 115: 81-87

Kohn AJ, Almasi KN (1993) Imposex in Australian Conus. J Mar Biol Assoc UK 73:241-244

Li ZY (2000) The incidence of imposex in Hong Kong and the value of Thais clavigera (Gastropoda: Muricidae) as a bioindicator of TBT pollution. PhD thesis, University of Hong Kong

Liu LL, Suen IJ (1996) Prosobranch gastropod imposex in the west coast of Taiwan. Venus 55 (3):207-214

Matthiessen P, Gibbs PE (1998) Critical appraisal of the evidence for tributyltin-mediated endocrine disruption in mollusks. Environ Toxicol Chem 17(1):37-43

Mensink BP, Kralt H, Vethaak AD, Ten Hallers-Tjabbes CC, Koeman JH, van Hattum B, Boon JP (2002) Imposex induction in laboratory reared juvenile Buccinum undatum by tributyltin (TBT). Environ Toxicol Phar 11(1):49-65

Minchin D, Bauer B, Oehlmann J, Schulte-Oehlmann SU, Duggan CB (1997) Biological indicators used to map organotin contamination from a fishing port, Killybegs, Ireland. Mar Pollut Bull 34(4):235-243

Nishikawa J, Mamiya S, Kanayama T, Nishikawa T, Shiraishi F, Horiguchi T (2004) Involvement of the retinoid X receptor in the development of imposex caused by organotins in gastropods. Environ Sci Technol 38:6271-6276

Oehlmann J, Stroben E, Fioroni P (1991) The morphological expression of imposex in Nucella lapillus (Linnaeus) (Gastropoda: Muricidae). J Molluscan Stud 57:375-390

Oehlmann J, Stroben E, Fioroni P (1992) The rough tingle Ocenebra erinacea (Gastropoda: Muricidae): an exhibitor of imposex in comparison to Nucella lapillus. Helgol Meeresunters 46:311-328

Oehlmann J, Fioroni P, Stroben E, Markert B (1996) Tributyltin (TBT) effects on Ocenebrina aciculata (Gastropoda: Muricidae): imposex development, sterilization, sex change and population decline. Sci Total Environ 188: 205-223

Oehlmann J, Stroben E, Schulte-Oehlmann U, Bauer B (1998) Imposex development in response to TBT pollution in Hinia incrassata (Ström, 1768) (Prosobranchia, Stenoglossa). Aquat Toxicol 43:239-260

Pellizzato F, Centanni E, Marin MG, Moschino V, Pavoni B

Editorial responsibility: Otto Kinne (Editor-in-Chief), Oldendorf/Luhe, Germany
(2004) Concentrations of organotin compounds and imposex in the gastropod Hexaplex trunculus from the Lagoon of Venice. Sci Total Environ 332:89-100

Power AJ, Keegan BF (2001) The significance of imposex levels and TBT contamination in the red whelk, Neptunea antiqua (L.) from the offshore Irish Sea. Mar Pollut Bull 42: 761-772

Ronis MJJ, Mason AZ (1996) The metabolism of testosterone by the periwinkle (Littorina littorea) in vitro and in vivo: effects of tributyltin. Mar Environ Res 42:161-166

Ruiz JM, Barreiro R, González JJ (2005) Biomonitoring organtotin pollution with gastropods and mussels. Mar Ecol Prog Ser 287:169-176

Shi HH, Huang CJ, Yu XJ, Zhu SX (2005) An updated scheme of imposex for Cantharus cecillei (Gastropoda: Buccinidae) and a new mechanism leading to the sterilization of imposex-affected females. Mar Biol 146:717-723

Smith BS (1971) Sexuality in the American mud snail, Nassarius obsoletus Say. Proc Malacol Soc Lond 39:377-378

Smith BS (1981a) Reproductive anomalies in stenoglossan snails related to pollution from marinas. J Appl Toxicol 1(1):15-21

Smith BS (1981b) Male characteristics on female mud snails caused by antifouling bottom paints. J Appl Toxicol 1(1): $22-25$

Smith BS (1981c) Tributyltin compounds induce male characteristics on female mud snails Nassarius obsoletus = Ilayanassa obsoleta. J Appl Toxicol 1(3):141-144

Spooner N, Gibbs PE, Bryan GW, Goad LJ (1991) The effect of tributyltin upon steroid titers in the female dogwhelk, Nucella lapillus, and the development of imposex. Mar Environ Res 32:37-49

Stewart C, de Mora SJ, Jones MRL, Miller MC (1992) Imposex in New Zealand Neogastropods. Mar Pollut Bull 24:204-209

Stroben E, Oehlmann J, Fioroni P (1992) The morphological expression of imposex in Hinia reticulata (Gastropoda: Buccinidae): a potential biological indicator of tributyltin pollution. Mar Biol 113:625-636

Tan KS (1999) Imposex in Thais gradata and Chicoreus capucinus (Mollusca, Neogastropoda, Muricidae) from the straits of Johor: a case study using penis length, area and weight as measures of imposex severity. Mar Pollut Bull 39:295-303

Terlizzi A, Geraci S, Gibbs PE (1999) Tributyltin (TBT)induced imposex in the Neogastropod Hexaplex trunculus in Italian coastal waters: morphological aspects and ecological implications. Mar Pollut Bull 36:749-752

Terlizzi A, Delos AL, Garaventa F, Faimali M, Geraci S (2004) Limited effectiveness of marine protected areas: imposex in Hexaplex trunculus (Gastropoda, Muricidae) populations from Italian marine reserves. Mar Pollut Bull 48: $164-192$

Submitted: November 3, 2004; Accepted: May 16, 2005 Proofs received from author(s): November 23, 2005 